\title{
PERAN DUKUNGAN SOSIAL ORANGTUA, TEMAN SEBAYA, DAN GURU TERHADAP SCHOOL WELL-BEING SISWA PESANTREN X
}

\author{
Irena Nova Wijaya ${ }^{1}$, Riana Sahrani ${ }^{2}$, Fransisca Iriani R. Dewi ${ }^{3}$ \\ ${ }^{1}$ Program Studi Magister Psikologi, Universitas Tarumanagara, Jakarta \\ Email: irena.707199201@stu.untar.ac.id \\ ${ }^{2}$ Fakultas Psikologi, Universitas Tarumanagara, Jakarta \\ Email: rianas@fpsi.untar.ac.id \\ ${ }^{3}$ Fakultas Psikologi, Universitas Tarumanagara, Jakarta \\ Email: fransiscar@fpsi.untar.ac.id
}

Masuk : 19-03-2020, revisi: 28-04-2020, diterima untuk diterbitkan : 30-04-2020

\begin{abstract}
Islamic boarding schools' education has its own challenges, higher academic loads, longer duration, and other rules that need to be followed. Students' experiences in school will shape students' judgment of their school. Students' judgment toward their school is defined as school well-being. Researches said that social support has roles in several school well-being dimensions. But there is no research linking social support with a whole school well-being's dimension. In addition, studies on social support variables (parents, teachers, and peers) and school well-being in the context of Islamic boarding schools are still limited. This study examines the role of parents', peer groups', and teachers' social support in X Islamic Boarding School regarding student's School Well-Being. This quantitative research, with purposive sampling technique, include 115 teenagers who live in X boarding school. X Islamic boarding school is a modern Islamic boarding school, accredited with $C$ grade, and most of the students come from disadvantaged families. Subject's average age is 17 years old with (33.9\%) boys and (66.1\%) girls. Data analysis was done with correlation and regression descriptive statistics. The main result of the research shows that parent's, peer groups', and teacher's social support have no role in X boarding school student's school well-being $(F=0,785, p=0,505>0,05)$. Further researches data shows parent's support, peer groups' support, teacher's support and school well-being in X Islamic boarding school classified as quiet high. Although, dimension having and being, classified as quiet low. Furthermore, there are parents', peer groups' and teachers' social support role in school well-being's loving dimension.
\end{abstract}

Keywords: social support, school well-being, educational psychology

\begin{abstract}
ABSTRAK
Pendidikan pesantren memiliki tantangan tersendiri, seperti beban akademis yang lebih tinggi, waktu yang lebih panjang, dan berbagai peraturan yang harus dijalankan. Pengalaman siswa di sekolah akan membentuk penilaian siswa terhadap sekolahnya. Penilaian siswa akan sekolahnya disebut school well-being. Beberapa penelitian menunjukkan dukungan sosial memiliki peran dalam beberapa dimensi dalam school well-being. Namun belum ada penelitian yang menghubungkan dukungan sosial dengan school well-being secara menyeluruh. Selain itu kajian mengenai varibel dukungan sosial (orangtua, guru, dan teman sebaya) dan school well-being dalam konteks pesantren atau sekolah asrama masih terbatas. Penelitian ini bertujuan menguji peran dukungan sosial orangtua, teman sebaya, dan guru terhadap school well-being di pesantren X. Sebanyak 115 remaja menjadi sampel diambil dengan purposive sampling yang berasal dari pesantren $\mathrm{X}$. Pesantren $\mathrm{X}$ adalah pesantren modern, terakreditasi C, dan sebagian besar siswa adalah kaum dhuafa. Rerata subyek adalah 17 tahun dengan jenis kelamin laki-laki $(33,9 \%)$ dan perempuan $(66,1 \%)$. Analisis data dilakukan dengan statistik deskriptif, uji korelasi, dan regresi. Hasil utama penelitian menunjukkan tidak terdapat peran dukungan sosial orangtua, teman sebaya, dan guru terhadap school well-being pada siswa pesantren $\mathrm{X}(\mathrm{F}=0,785, \mathrm{p}=0,505>0,05)$. Hasil penelitian tambahan menunjukkan gambaran dukungan orangtua, dukungan teman sebaya, dukungan guru, dan school well-being pesantren $\mathrm{X}$ tergolong cukup tinggi. Namun pada gambaran dimensi having dan being torgolong cukup rendah. Selanjutnya, terdapat peran dukungan sosial orangtua, dukungan sosial teman, dan dukungan sosial guru terhadap dimensi loving pada variabel school well-being.
\end{abstract}

Kata Kunci: dukungan sosial, school well-being, psikologi pendidikan. 


\section{PENDAHULUAN}

\section{Latar Belakang}

Siswa yang mengikuti pendidikan di pesantren memiliki jam belajar lebih panjang dan peraturan yang lebih menantang (Nugroho, 2011; Maulina, 2011). Pesantren X memulai kegiatan pukul empat pagi hingga pukul sebelas malam. Beberapa peraturan di pesantren yaitu dilarang membawa gadget, dilarang keluar-masuk area pesantren pada waktu tertentu dan tanpa izin, diwajibkan memakai pakaian tertutup, dilarang memiliki hubungan khusus dengan lawan jenis dan sebagainya. Selain itu fasilitas di Pesantren X juga terbatas seperti sarana olahraga, sarana musik, jumlah kamar mandi yang tidak sesuai dengan jumlah siswa, letak asrama laki-laki dan perempuan yang terlalu berdekatan, tidak ada perpustakaan dan unit kesehatan yang belum berkembang (AB, Komunikasi Personal, 8 Desember 2018).

Di sisi lain siswa dapat menikmati kehidupannya di pesantren dengan mengikuti kegiatan yang diminati melalui kegiatan ekstrakurikuler dan berbagai kompetisi (Komunikasi Personal, 25 Oktober 2018). Siswa tetap dapat berprestasi, siswa aktif mengikuti dan memenangkan lomba akademik dan non akademik seperti pramuka, paskibra, pidato, penyuluhan, hafalan hadits, dan tahfidz Al-Quran. Selain itu siswa diberikan tanggung jawab dengan berkontribusi dalam membuat peraturan di kelas. Siswa juga diajarkan untuk fasih public speaking, hal tersebut sesuai dengan cita-cita siswa untuk menjadi pendakwah (Komunikasi Personal, 25 Oktober 2018). Pengalaman siswa di sekolah memengaruhi penilaian siswa terhadap sekolahnya. School well-being merupakan penilaian subyektif individu terhadap kehidupan sekolahnya yang terkait dengan kondisi sekolah (having), hubungan sosial (loving), sarana pemenuhan diri (being), dan status kesehatan (health) (Konu \& Rimpela, 2002).

Meskipun tidak sebebas di rumah dan fasilitas terbatas, siswa merasa dorongan-dorongan dari guru membuat siswa ingin menjadi yang terbaik di kelas. Ketika siswa sedang merasa sedih, lelah, dan menangis karena tuntutan di sekolah, siswa akan mengingat dorongan yang diberikan orangtua (Komunikasi Personal, 25 Oktober 2018). Ketika jam istirahat beberapa siswa memilih untuk duduk bersama dan berbincang dengan teman sebaya (Komunikasi Personal, 13 November 2018). Namun ketika istirahat ada juga siswa yang memilih menyendiri dan tidur untuk menjauhi dirinya dari hal-hal negatif seperti membicarakan orang lain dengan teman (Komunikasi Personal, 25 Oktober 2018). Dengan kata lain dukungan sosial dari guru, orangtua, dan teman sebaya memiliki peran dalam kehidupan siswa di pesantren.

Siswa di pesantren memiliki tantangan yang lebih tinggi dibandingkan di sekolah umum, beban akademis yang lebih tinggi, waktu yang lebih panjang, dan peraturan yang banyak. Tekanan belajar sedang dapat meningkatkan perkembangan namun tekanan yang terlalu berat dapat membahayakan dan menyebabkan kerusakan fisik dan psikologis ( $\mathrm{Su}$, et al., 2012). Individu yang lebih sering terlibat dalam hubungan sosial serta memiliki peran sosial memiliki tingkat kepuasan dalam hidup yang lebih tinggi (Setyawan \& Dewi, 2015). Penelitian di pesantren juga menunjukkan dukungan sosial orangtua memiliki hubungan dengan motivasi belajar siswa (Malwa, 2017). Dengan kata lain siswa yang memiliki kepuasan hidup tinggi dan motivasi belajar disebabkan oleh dukungan sosial dari lingkungan.

Peneliti belum menemukan penelitian yang menghubungkan dukungan sosial dengan school well-being secara keseluruhan. Namun peneliti menemukan beberapa penelitian dukungan sosial secara umum yang berkaitan dengan beberapa dimensi school well-being. Dukungan sosial cenderung meningkatkan prestasi, produktivitas, dan kesehatan fisik (Johnson \& Johnson, 2013). 
Sekolah yang memberikan kesempatan siswa untuk meningkatkan pengetahuan dan keterampilan merupakan bagian dari sarana self fulfilment (being) siswa di sekolah pada variabel school well-being (Konu \& Rimpela, 2002). Dukungan sosial memiliki pengaruh terhadap resiliensi pada individu yang mengalami intimidasi (Alvina \& Dewi, 2016). Intimidasi dapat dilihat sebagai fenomena kelompok berdasarkan hubungan sosial (loving) dan peran dalam kelompok dalam variabel school well-being (Salmivallu dalam Konu \& Rimpela, 2002). Dukungan sosial yang lebih besar secara signifikan terkait dengan hasil tidur yang lebih baik (Grey, Uchino, Trettevik, Cronan \& Hogan, 2018). Kesehatan memiliki hubungan dengan dukungan sosial melalui partisipasi agama (George \& Taylor dalam King, 2011). Kesehatan (health) juga merupakan hal penting untuk mencapai kesejahteraan (Konu \& Rimpela, 2002). Dengan kata lain dukungan sosial secara umum memiliki peran dalam dimensi health, loving, dan being pada school well-being.

Pada penelitian menunjukkan terdapat hubungan dukungan sosial orangtua dan iklim sekolah terhadap kepuasan hidup remaja (Zulaikhah, 2017). Selain itu, orangtua memainkan peranan yang penting pada anak yang melakukan tindakan intimidasi ke lingkungan sosialnya (Usman, 2013). Intimidasi dapat dilihat sebagai fenomena kelompok berdasarkan hubungan sosial (loving) dan peran dalam kelompok (Salmivallu dalam Konu \& Rimpela, 2002). Iklim sekolah merupakan aspek dari dimensi loving serta memiliki efek pada kesejahteraan dan kepuasan murid di sekolah (Konu \& Rimpela, 2002). Dengan kata lain dukungan orangtua memiliki peran dalam dimensi loving pada school well-being.

Dukungan sosial teman sebaya berperan dalam peningkatan prestasi belajar dan keyakinan akan kemampuan untuk berhasil di sekolah (Solomon, 2004; Halimah, Kusdiyati, \& Susandari, 2017). Di samping itu dukungan sosial teman sebaya berperan dalam penyesuaian diri bersosialisasi (East, Hess, \& Lerner, 1987). Kesempatan untuk meningkatkan pengetahuan dan keterampilan merupakan sarana pemenuhan diri yang disebut being dalam school well-being (Konu \& Rimpela, 2002). Hubungan dengan teman sebaya, dan dinamika kelompok merupakan aspek dari hubungan sosial (loving) dalam school well-being (Konu \& Rimpela, 2002). Dengan kata lain dukungan sosial teman sebaya berperan dalam dimensi loving pada varibel school well-being.

Dukungan sosial guru berhubungan dengan prestasi siswa, harga diri, dan kepuasan terhadap sekolah, dan kesejahteraan subyektif di sekolah (Tian, Zao, \& Huebner, 2015; Aldrup, Klusmann, Lüdtke, Göllner, \& Trautwein, 2018). Selanjutnya penelitian yang menghubungkan kedekatakan siswa dengan guru menunjukkan siswa mengalami peningkatan akademik dan secara sosial dari hubungan siswa dan guru yang positif (Cataldi, Laird, \& KewalRamani, 2009). Kajian mengenai varibel dukungan sosial (orangtua, teman sebaya, dan guru) dan school wellbeing dalam konteks pesantren atau sekolah asrama masih terbatas. Hal ini menjadi alasan peneliti untuk menguji lebih lanjut mengenai dukungan sosial dan school well-being. Sebelumnya penelitian yang mengaitkan dukungan sosial orangtua, dukungan sosial teman, dukungan guru, dan school well-being telah dilakukan di Cina (Tian, Liu, Huang, \& Huebner, 2013). Namun peneliti menggunakan alat ukur untuk mengukur subjective well-being di sekolah yang dirasakan oleh remaja. Subskalanya antara lain kepuasan secara umum, pengaruh positif, dan pengaruh negatif. Pada penelitian tersebut subyek juga diambil di sekolah umum, dengan status sosial dan ekonomi tingkat menengah, serta dilakukan di Cina.

Penelitian lain yang menghubungkan antara dukungan sosial orangtua, teman sebaya, dan guru dengan kesejahteraan remaja juga telah dilakukan di Brazil (Leme, Prette, \& Coimbra, 2015). Namun peneliti mengunakan alat ukur untuk mengukur psychological well-being yang dirasakan 
remaja. Subskalanya antara lain hubungan positif dengan orang lain, otonomi, environmental mastery, personal growth, purpose in life, dan self-acceptance. Pada penelitian tersebut subyek juga diambil dari sekolah umum bukan asrama.

Penggunaan pengukuran school well-being berdasarkan temuan Konu dan Rimpela (2002) dengan dimensi having, loving, being dan health masih sangat terbatas. Dimensi-dimensi ini tidak hanya mengukur pada hal yang bersifat psikis namun juga fisik pada konteks sekolah, seperti pada dimensi health. Health mengacu kepada status kesehatan yang terdiri dari gejala fisik dan mental, flu, dan penyakit-penyakit kronis lainnya (Konu \& Rimpela, 2002). Selain itu Konu dan Rimpela (2002) tidak hanya mengukur pada hal yang bersifat internal namun juga eksternal, seperti pada dimensi having. Having mengacu pada kondisi sekolah seperti kondisi material dan kebutuhan impersonal dalam perspektif yang luas (Konu \& Rimpela, 2002).

Berdasarkan fenomena dan kajian literatur yang dilakukan peneliti dapat disimpulkan dukungan sosial orangtua, teman sebaya, dan guru memiliki peran dalam kehidupan siswa di sekolah melalui dimensi-dimensi tertentu pada varibel school well-being. Tujuan dari penelitian ini adalah untuk menguji peran dukungan sosial orangtua, teman sebaya, dan guru terhadap school well-being pada siswa di pesantren X. Sehingga hasil dapat menjadi evaluasi bagi para peneliti, pihak sekolah, maupun orangtua untuk membawa kemajuan bagi masing-masing pihak.

\section{Rumusan Masalah}

Rumusan permasalahan dalam penelitian ini adalah adakah peran dukungan sosial orangtua, teman sebaya dan guru terhadap school well-being siswa di pesantren X.

\section{METODE PENELITIAN}

Partisipan dalam penelitian ini adalah (a) berjenis kelamin laki-laki dan perempuan, (b) terdaftar sebagai siswa tingkat Sekolah Menengah Atas di pesantren X, dan (c) bermukim di pondok pesantren X. Pada penelitian ini teknik pengambilan sampel dilakukan dengan purposive sampling pada nonprobability sampling. Populasi siswa yang bersekolah dan bermukim di Pesantren X sebanyak 159 siswa. Sedangkan sampel berjumlah 115 yaitu siswa yang menyelesaikan kuesioner dengan lengkap.

Metode penelitian yang digunakan adalah kuantitatif non-experimental karena mengukur variabel yang sudah terjadi pada partisipan (tidak ada manipulasi). Peralatan penelitian ini berupa kuesioner untuk mengumpulkan data dari subyek. Penelitian yang dilakukan adalah untuk melihat peran dukungan sosial orangtua, teman sebaya, dan guru terhadap school well-being. Selain itu penelitian ini juga menggunakan metode statistika regresi linier berganda. Teknik penghitungan regresi berganda ini dilakukan dengan bantuan software SPSS.

\section{Pengukuran Penelitan}

Pada penelitian ini digunakan dua alat ukur yaitu CASSS (Child and Adolescent Social Support) dan The School Well-Being Model. Peneliti melakukan uji validitas dan reliabilitas untuk seluruh alat ukur. Validitas isi yang digunakan adalah expert judgment kepada tiga pakar. Peneliti juga melakukan analisis butir dengan menggunakan Corrected Item Total Correlation. Dalam uji validitas seluruh butir memiliki $r$ di atas 0.2 maka butir dinyatakan valid. Uji reliabilitas alat ukur dilakukan dengan membandingkan koefisien Alpha Cronbach pada setiap dimensi alat ukur dengan standar minimal yang diterima yaitu $\alpha>.50$. 
Definisi konseptual dukungan sosial adalah persepsi individu akan dukungan umum atau perilaku dukungan khusus yang didapatkan dari lingkungannya untuk meningkatkan fungsi kehidupan atau melindungi individu dari hal-hal yang merugikan (Malecki, Demaray, \& Elliot, 2000). Adapun dimensi dukungan sosial adalah emosional, instrumen, penilaian, dan informasi (Malecki, Demaray, \& Elliot, 2000). Definisi operasional dari dukungan sosial adalah individu dikatakan memiliki dukungan sosial yang tinggi apabila skor dukungan sosial yang ditinjau dari setiap dimensi emosional, instrumen, penilaian, dan informasi juga tinggi. CASSS dirancang untuk mengukur dukungan sosial yang diterima individu di sekolah.

Definisi konseptual school well-being adalah penilaian subyektif individu terhadap kehidupan sekolahnya yang terkait dengan dimensi having, loving, being, dan health (Konu \& Rimpela, 2002). Definisi operasional dari school well-being adalah seseorang dikatakan memiliki school well-being yang tinggi apabila skor school well-being yang ditinjau dari setiap dimensi having, loving, being, dan health juga tinggi yang diukur dengan kuesioner The School Well-Being Model. Selengkapnya dapat dilihat pada tabel 1 dan tabel 2.

Tabel 1. Ringkasan uji reliabilitas

\begin{tabular}{cccc}
\hline Variabel Dukungan Sosial & Dimensi & Butir Positif & Alpha Cronbach \\
\hline Orangtua & Emosional & 3 & .587 \\
Teman & & 6 & .787 \\
Guru & & 3 & .675 \\
\hline Orangtua & Informasi & 3 & .654 \\
Teman & & 6 & .820 \\
Guru & & 3 & .630 \\
\hline Orangtua & Penilaian & 3 & .616 \\
Teman & & 6 & .774 \\
Guru & & 3 & .665 \\
\hline Orangtua & Instrumen & 3 & .601 \\
Teman & & 6 & .806 \\
Guru & 3 & .668 \\
\hline
\end{tabular}

Tabel 2. Ringkasan uji reliabilitas

\begin{tabular}{ccccc}
\hline Alat ukur & dimensi & Jumlah Butir & Alpha Cronbach \\
\hline The School Well-Being Model & Having & positif & negatif \\
& Loving & 1 & 12 & .850 \\
& Being & 1 & 2 & .515 \\
& Health & & 9 & .831 \\
& & & & .789 \\
\hline
\end{tabular}

\section{HASIL DAN PEMBAHASAN}

\section{School Well- Being Siswa}

Gambaran variabel-variabel dalam penelitian ini, yakni dukungan sosial orang tua, dukungan sosial teman sebaya, dukungan sosial guru dan school well-being didapatkan dengan melakukan analisis descriptive statistic. Nilai rata-rata dukungan sosial orangtua yang dimiliki subyek lebih tinggi dibandingkan dengan nilai titik tengah alat ukur, yaitu 2.5. Artinya subyek mempersepsikan dukungan umum atau khusus yang didapat dari orangtuanya dapat meningkatkan fungsi kehidupan atau melindungi subyek dari hal-hal yang yang merugikan. Nilai rata-rata dukungan sosial teman sebaya yang dimiliki subyek lebih tinggi dibandingkan dengan 
nilai titik tengah alat ukur, yaitu 2.5. Artinya subyek mempersepsikan dukungan umum atau khusus yang didapat dari teman sebaya dapat meningkatkan fungsi kehidupan atau melindungi subyek dari hal-hal yang merugikan. Nilai rata-rata dukungan sosial guru yang dimiliki subyek lebih tinggi dibandingkan dengan nilai titik tengah alat ukur, yaitu 2.5. Artinya subyek mempersepsikan dukungan umum atau khusus yang didapat dari guru dapat meningkatkan fungsi kehidupan atau melindungi subyek dari hal-hal yang yang merugikan. Nilai rata-rata school well-being yang dimiliki subyek lebih tinggi dibandingkan dengan nilai titik tengah alat ukur, yaitu 2.5. Artinya subyek menilai baik kehidupan sekolahnya yang terkait dengan dimensi having, loving dan health.

Analisis dimensi dari school well-being, yaitu having, loving dan health juga dilakukan. Nilai rata-rata having yang dimiliki subyek lebih rendah dibandingkan dengan nilai titik tengah alat ukur, yaitu 2.5. Artinya subyek mempersepsikan kondisi sekolah seperti kondisi material dan kebutuhan impersonal dalam perspektif yang luas tergolong rendah. Nilai rata-rata loving yang dimiliki subyek lebih tinggi dibandingkan dengan nilai titik tengah alat ukur, yaitu 2.5. Artinya subyek mempersepsikan kebutuhan untuk berhubungan dengan orang lain dan untuk membentuk identitas sosial yang didapat tergolong tinggi. Nilai rata-rata being yang dimiliki subyek lebih rendah dibandingkan dengan nilai titik tengah alat ukur, yaitu 2.5. Artinya subyek mempersepsikan self fulfilment yang meliputi makna akan tugas siswa, kesempatan yang diberikan, arahan, dorongan, pengaruh sekolah dalam pengambilan keputusan, peningkatan harga diri, penggunaan kreativitas dan sebagainya yang didapat tergolong rendah. Nilai rata-rata health yang dimiliki subyek lebih tinggi dibandingkan dengan nilai titik tengah alat ukur, yaitu 2.5. Artinya subyek mempersepsikan status kesehatan tergolong tinggi.

Data demografi subyek penelitian meliputi jender, usia, tingkat atau kelas. Selain itu dideskripsikan alasan menajdi bagian atau mengikuti pendidikan di pesantren. Secara lengkap tersaji dalam tabel 3, 4, 5 dan 6 .

Tabel 3. Gambaran jenis kelamin

\begin{tabular}{ccc}
\hline Jenis Kelamin & Frekuensi & Persentase (\%) \\
\hline Laki-laki & 39 & 33,9 \\
Perempuan & 76 & 66,1 \\
\hline Total & 115 & 100 \\
\hline
\end{tabular}

Tabel 4. Gambaran usia

\begin{tabular}{ccc}
\hline Usia & Frekuensi & Persentase (\%) \\
\hline 14 & 3 & 2,6 \\
15 & 35 & 30,4 \\
16 & 30 & 26,1 \\
17 & 39 & 33,9 \\
18 & 7 & 6,1 \\
19 & 1 & 0,9 \\
\hline Total & 115 & 100 \\
\hline
\end{tabular}


Tabel 5. Tingkat kelas

\begin{tabular}{ccc}
\hline Kelas & Frekuensi & Persentase (\%) \\
\hline 1 SMA & 32 & 27,8 \\
2 SMA & 39 & 33,9 \\
3 SMA & 44 & 38,3 \\
\hline Total & 115 & 100 \\
\hline
\end{tabular}

Tabel 6. Alasan masuk pesantren

\begin{tabular}{ccc}
\hline Alasan Masuk Pesantren & Frekuensi & Persentase (\%) \\
\hline Keinginan sendiri & 46 & 40 \\
Keinginan orangtua & 69 & 60 \\
\hline Total & 115 & 100 \\
\hline
\end{tabular}

Untuk menguji peran dukungan sosial orangtua, dukungan sosial teman sebaya dan dukungan sosial guru terhadap school well-being. Peneliti menggunakan uji regresi berganda (multiple regression). Berdasarkan hasil diketahui bahwa tidak terdapat peran dari dukungan sosial orangtua, dukungan sosial teman sebaya dan dukungan sosial guru terhadap school well-being siswa pesantren. Hal ini ditunjukan dari nilai $F=0,785$ dan $p=0,505>0,05$. Nilai $R^{2}=0,021$ menunjukan bahwa sumbangan dukungan sosial orangtua, dukungan sosial teman, dan dukungan sosial guru sebesar 2,1\% sedangkan sisanya dipengaruhi faktor lain. Selengkapnya dapat dilihat pada tabel 3

Tabel 7. Analisis regresi school well-being

\begin{tabular}{cccc}
\hline Variabel & $\mathrm{R} 2$ & $\mathrm{~F}$ & Sig. \\
\hline School Well-being & 0,021 & 0,785 & 0,505 \\
\hline
\end{tabular}

Peneliti juga melakukan analisis per dimensi, yaitu menguji peran dukungan sosial orangtua, dukungan sosial teman sebaya dan dukungan guru terhadap dimensi-dimensi dari school wellbeing. Berdasarkan hasil analisis data uji regresi diketahui bahwa (a) tidak terdapat peran dari dukungan sosial orangtua, dukungan sosial teman, dan dukungan sosial guru terhadap dimensi having dengan nilai signifikansi $0.436>0.05$, (b) terdapat peran dari dukungan sosial orangtua, dukungan sosial teman, dan dukungan sosial guru terhadap dimensi loving dengan nilai signifikansi $0.008<0.05$, (c) tidak terdapat peran dari dukungan sosial orangtua, dukungan sosial teman, dan dukungan sosial guru terhadap dimensi being dengan nilai signifikansi $0.413>0.05$, (d) tidak terdapat peran dari dukungan sosial orangtua, dukungan sosial teman, dan dukungan sosial guru terhadap dimensi health dengan nilai signifikansi $0.723>0.05$.

Pada hasil penelitian tidak terdapat peran dukungan sosial orang tua, teman sebaya, dan guru terhadap school well-being. Berbagai penelitian menunjukkan, ada perbedaan antara masyarakat Eropa Amerika, dengan masyarakat Asia. Masyarakat Asia lebih memerhatikan mencari dukungan sosial akan mengganggu hubungan mereka dengan orang lain, kurang mau mencari dukungan sosial eksplisit untuk menghadapi peristiwa yang membuat stres, dukungan sosial tidak memiliki manfaat langsung atau peningkatan pada masyarakat Asia (Kim, Sherman, Ko, \& Taylor, 2006; Taylor, Welch, Kim, \& Sherman, 2007; Chiang, Saphire-Bernstein, Kim, Sherman, \& Taylor, 2012). Selain itu, masyarakat Asia mencari dukungan sosial yang tidak diminta untuk mengurangi stress daripada dukungan sosial yang diminta, yang menunjukkan keprihatinan mereka dengan biaya sosial dalam mencari dukungan dari orang lain (Mojaverian \& Kim, 2013). Meminta dukungan sosial dapat menimbulkan keprihatinan yang lebih besar untuk 
hasil relasi yang berpotensi negatif (Kim et al., 2006; Taylor et al., 2004). Pandangan mengenai dukungan sosial tersebut dapat menjadi alasan mengapa dukungan sosial tidak memiliki peran dalam school well-being. Karena ketika siswa memiliki masalah terhadap pengalamannya di sekolah. Siswa cenderung tidak mencari dukungan sosial untuk menghindari hal-hal yang tidak diharapkan.

Berbagai pendekatan untuk gangguan mental telah muncul diberbagai budaya. Salah satu model penyembuhan dalam masyarakat non-barat adalah fokus pada spiritual dan agama (Heine, 2016). Gangguan mental sering dianggap sebagai akar dalam masalah spiritual, dan pengobatan sering diserahkan kepada tabib tradisional (Heine, 2016). Kesehatan mental yang positif melibatkan rasa kesejahteraan psikologis, yang berjalan seiring dengan perasaan diri yang sehat (Keyes, Shapiro, Ryff \& Singer dalam Papalia \& Feldman, 2012). Hal ini dapat menjadi penyebab mengapa dukungan sosial tidak berperan dalam school well-being siswa pesantren. Ketika siswa merasa terdapat masalah mengenai hal yang berkaitan dengan school well-being siswa cenderung mencari solusi dengan hal-hal spiritual dibandingkan dengan mencari dukungan sosial dengan orang lain.

Pada hasil analisis tambahan menunjukkan terdapat peran dari dukungan sosial orang tua, teman sebaya, dan guru terhadap dimensi loving. Loving atau hubungan sosial mengacu pada kebutuhan untuk berhubungan dengan orang lain dan identitas sosial (Konu \& Rimpela, 2002). Penelitian dengan subyek siswa pesantren menunjukkan salah satu faktor positif kesejahteraan subyektif adalah teman yang menyenangkan (Hamdana \& Alhamdu, 2015). Berdasarkan observasi dan wawancara peneliti kehidupan di pesantren dilakukan dengan kolektif. Siswa melakukan berbagai kegiatan bersama-sama dari membersihkan asrama, menghafal pelajaran, mempersiapkan perlombaan, dan sebagainya. Dengan demikian, hubungan interpersonal antara individu memiliki peran dalam kebutuhan siswa berhubungan dengan orang lain.

Pada gambaran dimensi loving dan health di variabel school well being tergolong cukup tinggi. Penelitian dengan subyek siswa pesantren menunjukkan salah satu faktor positif kesejahteraan subyektif adalah teman yang menyenangkan (Hamdana \& Alhamdu, 2015). Aspek penting dari hubungan sebaya yang positif adalah memiliki satu atau lebih teman dekat (King, 2011). Remaja dapat belajar menjadi teman yang terampil dan peka dalam hubungan intim dengan menjalin persahabatan dekat dengan teman sebaya yang dipilihnya (King, 2011). Teman yang menyenangkan dan persahabatan dengan teman sebaya dipilih dapat menjadi faktor mengapa loving pada variabel school well-being tergolong cukup tinggi. Selanjutnya, sejumlah penelitian menghubungkan partisipasi keagamaan dengan kehidupan yang lebih sehat (Campbell, Yoon, \& Johnstone, 2010; McCullough \& Willoughby, 2009). Kehidupan siswa di pesantren yang kental dengan partisipasi agama dapat menyebabkan kehidupan siswa yang cenderung sehat. Penelitian yang membandingkan kalangan status sosial dan ekonomi rendah (Latina) dengan tinggi (nonLatina) menunjukkan tidak semua kalangan yang tidak beruntung menderita kesehatan yang buruk (National Center for Health Statistics dalam Heine, 2016). Hasil positif ini disebabkan oleh keterlibatan pada perilaku yang cenderung menyehatkan dibandingkan kalangan ekonomi tinggi, seperti tidak merokok dan meminum alkohol (Heine, 2016). Pada kehidupan pesantren siswa cenderung tidak dapat melakukan perilaku tidak menyehatkan karena tidak dapat menyimpan materi terlalu banyak, serta urusan konsumsi dan istirahat yang berhubungan dengan kesehatan diatur oleh sekolah. 
Gambaran dimensi having dan being dalam school well-being cukup rendah. Faktor-faktor negatif yang memengaruhi kesejahteraan subyektif siswa pesantren adalah fasilitas asrama yang masih kurang serta kegiatan yang terlalu padat dan monoton (Hamdana \& Alhamdu, 2015). Sekolah yang dihadiri oleh anak-anak dari latar belakang kemiskinan seringkali memiliki sumber daya yang lebih rendah daripada sekolah-sekolah di lingkungan berpenghasilan tinggi (Huston \& Bentley, 2010). Rendahnya having dapat disebabkan oleh status akreditasi pesantren X adalah C, sehingga untuk fasilitas masih terbatas. Berdasarkan obervasi dan wawancara peneliti terhadap siswa pesantren X. Pesantren X pada tingkat SMA belum mempunyai perpustakaan, ruang kamar mandi asrama dan sekolah yang terbatas, serta asrama putra dan putri yang berdekatan sehingga membuat siswa tidak nyaman. Kegiatan siswa yang padat dan monoton serta kemiskinan dapat menjadi penyebab kesempatan siswa untuk pemenuhan diri (being) menjadi terbatas. Pengalaman kemiskinan yang sangat tinggi mengarah pada defisit kognitif yang dapat merusak pengambilan keputusan (Mani, Mullainathan, Shafor, \& Zhao, 2013). Sekolah yang dihadiri oleh anak-anak dari latar belakang kemiskinan juga cenderung dikelola oleh guru-guru muda yang kurang berpengalaman dibandingkan sekolah di lingkungan berpenghasilan tinggi (Huston \& Bentley, 2010). Hal ini sesuai dengan observasi peneliti ketika mendatangi pesantren, peneliti menemui beberapa pengajar yang berusia 20-30 tahun. Guru-guru yang kurang berpengalaman dapat menyebabkan kurangnya bimbingan dan dorongan terhadap siswa. Bimbingan dan dorongan merupakan aspek dari dimensi being (Konu \& Rimpela, 2002).

\section{KESIMPULAN DAN SARAN}

Hasil dari penelitian menunjukkan tidak terdapat peran dukungan sosial orang tua, teman sebaya, dan guru terhadap school well-being siswa di pesantren X. Kondisi ini dimungkinkan karena pada dasarnya dukungan sosial orang tua, teman sebaya, dan guru memang sudah tergolong tinggi di pesantren $\mathrm{X}$ ini. Kemudian, hasil penelitian tambahan menunjukkan bahwa dimensi having dan being pada siswa pesantren $\mathrm{X}$ torgolong cukup rendah. Walau demikian, terdapat peran dukungan sosial orangtua, dukungan sosial teman, dan dukungan sosial guru terhadap dimensi loving pada variabel school well-being.

Saran untuk penelitian berikutnya adalah penelitian sejenis ini dapat dilakukan dengan skala subyek yang lebih besar agar mendapat gambaran yang lebih luas. Penelitian dengan jangka waktu yang lebih panjang akan sangat membantu dalam menyempurnakan penelitian sejenis. Peneliti juga disarankan lebih memerhatikan data kontrol seperti status sosial, ekonomi dan budaya. Terakhir, peneliti menyarankan melakukan penelitian serupa namun dengan subyek dengan status sosial dan ekonomi yang lebih tinggi sebagai bahan perbandingan.

\section{Ucapan Terima Kasih (Acknowledgement)}

Ucapan terima kasih disampaikan kepada berbagai pihak antara lain kepala sekolah, guru dan khususnya para siswa-siswi Pesantren X yang terlibat dalam penelitian ini.

\section{REFERENSI}

Aldrup, K., Klusmann, U., Lüdtke, O., Göllner, R., \& Trautwein, U. (2018). Social support and classroom management are related to secondary students' general school adjustment: A multilevel structural equation model using student and teacher ratings. Journal of Educational Psychology,1-18. doi: http://dx.doi.org/10.1037/edu0000256

Alvina, S., \& Dewi, F. I. R. (2016). Pengaruh harga diri dan dukungan sosial terhadap resiliensi mahasiswa dengan pengalaman bullying di perguruan tinggi. Jurnal Psikologi Psibernetika, 9(2), 156-162. 
Campbell, J. D., Yoon, D. P., \& Johnstone, B. (2010). Determining relationships between physical health and spiritual experience, religious practice, and congregational support in a heterogeneous sample. Journal of Religion and Health, 49, 3-17.

Cataldi, E. F., Laird, J., \& Kewalramani, A. (2009). High school dropout and completion rates in the United States:2007. Washington: National Center for Education Statistics.

Chiang, J. J., Saphire-Bernstein, S., Kim, H. S., Sherman, D. K., \& Taylor, S. E. (2012). Cultural differences in the link between supportive relationships and proinflammatory cytokines. Social Psychological and Personality Science, 4, 511-520.

East, P. L., Hess, L. E., \& Lerner, R. M. (1987). Peer social support and adjustment of early adolescent peer groups. The Journal of Early Adolescence, 7(2), 153-163.

Grey, R. G. K., Uchino, B. N., Trettevik, R., Cronan, S., \& Hogan, J. N. (2018). Social support and sleep: A meta-analysis. Health Psychology, 37(8), 787-798.

Johnson, D. W., \& Johnson, F. P. (2013). Joining together: Group theory and group skills. London: Pearson Education Limited.

Halimah, L., Kusdiyati, S., \& Susandari. (2017). Pengaruh konteks teman sebaya terhadap keterlibatan belajar dengan mediator self-system processes. Psymphatic, 4(2), 265-274.

Hamdana, F., \& Alhamdu. (2015). Subjective well-being siswa Man 3 Palembang yang tinggal di asrama. Psikis, 1(1), 95-104.

Heine, S. J. (2016). Cultural psychology ( $3^{\text {rd }}$ ed.). New York: W. W. Norton \& Company.

Huston, A. C. \& Bentley, A. C. (2010). Human development in societal context. Annual Review of Psychology, 61, 411-437.

Kim, H. S., Sherman, D. K., Ko, D., \& Taylor, S. E. (2006). Pursuit of comfort and pursuit of harmony: Culture, relationships, and social support seeking. Personality and Social Psychology Bulletin, 32, 1595-1607.

King, L. A. (2011). The science of psychology ( $2^{\text {nd }}$ ed.). New Yok: McGraw Hill.

Konu, A., \& Rimpela, M. (2002). Well-being in schools: A conceptual model. Health Promotion International, 17(1), 79-87.

Leme, V. B. R., Prette, Z. A. P. D., \& Coimbra, S. (2015). Social skills, social support and well-being in adolescents of different family configurations. Paidéia, 25(60), 9-18.

Malwa, R. U. (2017). Dukungan sosial orangtua dengan motivasi belajar siswa putra tahfidz Al-quran. Psikis, 3(2), 137-144.

Malecki, C. K., Demaray, M. K., \& Elliott, S. N. (2000). The child and adolescent social support scale. DeKalb: Northern Illinois University

Mani, A., Mullainathan, S., Shafir, E., \& Zhao, J. (2013). Poverty impedes cognitive function. Science, 341, 976-980.

Maulina, R. (2011). Boarding school tombak kesuksesan pendidikan berkarakter [Web log post]. Diunduh dari https://www.kompasiana.com/rufidz/boarding-school-tombak-kesuksesanpendidikan-berkarakter_550b16a28133117713b1e51d

McCullough, M. E., \& Willoughby, B. L. (2009). Religion, self-regulation, and self-control associations, explanations, and implications. Psychological Bulletin, 135, 69-93.

Mojaverian, T., \& Kim, H. S. (2013). Interpreting a helping hand cultural variation in the effectiveness of solicited and unsolicited social support. Personality and Social Psychology Bulletin, 39, 88-99.

Nugroho, A. (2011). Mengintip sekolah Islam modern berasrama. BBC Indonesia. Diunduh dari http://www.bbc.com

Papalia, D. E. \& Feldman, R. D. (2012). Experience human development (12 ${ }^{\text {th }}$ ed.). New York: McGraw-Hill 
Setyawan, I., \& Dewi, K. S. (2015). Kesejahteraan sekolah ditinjau dari orientasi belajar mencari makna dan kemampuan empati siswa sekolah menengah atas. Jurnal Psikologi Undip, 14(1), 9-20.

Solomon, P. (2004). Peer support/peer provided services underlying processes, benefits, and critical ingredients. Psychiatric Rehabilitation Journal, 27(4), 392- 401.

Su, C., Ma, L., Hewitt, P. L., Flett, G. L., \& Guo, L. (2012). Perfectionism, educational stress, and academic burnout in chinese adoloscents. Paper presented at the American Psychological Association 2012 Convention Presentation.

Taylor, S. E., Sherman, D. K., Kim, H., Jarcho, J. S., Takagi, k., \& Dunagan, M. S. (2004). Cultural and social support: Who seeks it and why. Journal of Personality and Social Psychology, 87, 354-362.

Taylor, S. E., Welch, W. T., Kim, H. S., \& Sherman, D. K. (2007). Cultural differences in the impact of social support on psychological and biological stress responses. Psychological Science, 18, 831-837.

Tian, L., Liu, B., Huang, S., \& Huebner. E. S. (2013). Perceived social support and school wellbeing among chines early dan middle adolescents: The mediational role of self-esteem. Social Indicators Research, 113, 991-1008.

Tian, L., Zhao, J., \& Huebner, E. S. (2015). School-related social support and subjective wellbeing in school among adolescents: The role of self-system factors. Journal of Adolescence, 45, 138-148.

Usman, I. (2013). Kepribadian, komunikasi, kelompok teman sebaya, iklim sekolah dan perilaku bullying. Humanitas, 10(1), 49-60.

Zulaikhah, S. (2017). Hubungan antara persepsi dukungan sosial orangtua dan iklim sekolah dengan kepuasan hidup pada remaja awal (Tesis Master, Universitas Gadjah Mada). Diunduh dari http://etd.repository.ugm.ac.id 